\title{
EFFECTS OF DIFFERENT TEMPERATURE CONDITIONS ON YIELD AND PHYSIOLOGICAL PROPERTIES OF RICE (ORYZA SATIVA L.)
}

\author{
HE, L. X. ${ }^{1,2 \#}-$ CHEN, Y. L. ${ }^{1 \#}-$ ZHANG, T. T. ${ }^{1,2 \#}-$ ZHENG, A. X. ${ }^{1,2 \#}-$ CHENG, Y. ${ }^{1}-$ DU, ${ }^{3}{ }^{3}-$ \\ LAI, R. F. ${ }^{1,2}-$ LU, R. $H^{1}-$ LUO, H. W. ${ }^{1,2}-$ LIU, Y. F. ${ }^{1,2}-$ TANG, X. R. ${ }^{1,2 *}$ \\ ${ }^{I}$ Department of Crop Science and Technology, College of Agriculture, South China Agricultural \\ University, 510642 Guangzhou, PR China \\ ${ }^{2}$ Scientific Observing and Experimental Station of Crop Cultivation in South China, Ministry of \\ Agriculture, 510642 Guangzhou, PR China \\ ${ }^{3}$ Key Laboratory of Key Technology for South Agricultural Machine and Equipment, Ministry of \\ Education, 510642 Guangzhou, PR China \\ ${ }^{\#}$ These author have contributed equally to this work \\ *Corresponding author \\ e-mail: tangxr@scau.edu.cn; phonelfax: +20-8528-0204-618 \\ (Received $3^{\text {rd }}$ Sep 2018; accepted $1^{\text {st }}$ Nov 2018)
}

\begin{abstract}
Temperature is one of the major factors which have a significant effect on plants. This study was carried out to investigate the effect of temperature variation on physio-biochemical characteristics of two rice cultivars i.e., Basmati385 and Xiangyaxiangzhan. A pot experiment with three different treatments of day-night temperature dynamics was carried out in a randomized complete block design with three replications. Treatments included T1: $33^{\circ} \mathrm{C} / 27^{\circ} \mathrm{C}, \mathrm{T} 2: 27^{\circ} \mathrm{C} / 21^{\circ} \mathrm{C}, \mathrm{T} 3: 21 / 15^{\circ} \mathrm{C}$ under $1200 \mathrm{X}$ yellow light intensity and $75 \%$ humidity. Results revealed that increase in temperature enhances photosynthesis, the production of photosynthetic pigments, but such increment was higher in Xiangyaxiangzhan than in Basmati385. Furthermore, temperature variably affected protein synthesis, and the activities of enzymatic antioxidants viz., superoxide dismutase (SOD), peroxidases (POD), catalase (CAT) in both cultivars. Moreover, the highest yield was recorded at $27^{\circ} \mathrm{C} / 21^{\circ} \mathrm{C}$ for both cultivars and the temperature of $27^{\circ} \mathrm{C} / 21^{\circ} \mathrm{C}$ was regarded as the most suitable temperature at filling stage for rice compared with $33^{\circ} \mathrm{C} / 27^{\circ} \mathrm{C}$ and $21 / 15^{\circ} \mathrm{C}$.
\end{abstract}

Keywords: rice, temperature stress, antioxidant enzyme, chlorophyll content, yield

\section{Introduction}

Temperature is a vital ecological variable which determines the growth of plants (Berry and Bjorkman, 2003) and the physiological and plant biochemical reactions such as respiration, protein synthesis and photosynthesis must be carried out under certain temperature conditions. The report of Atkin and Tjoelker (2003) indicated temperaturemediated changes in plant respiration are now accepted as an important component of the biosphere's response to global climate change and temperature is also a major driver of climate change affecting global food production. In spite of the challenges faced due to changing climate, global food production needs to increase by about $70 \%$ by 2050 , to feed the growing population (Almeselmani et al., 2006). Rice (Oryza sativa L.) is the most important cereal feeding more than 3 billion people globally and contributes about $20 \%$ to the total calorie intake of humans. Crops are altogether living in specific temperature conditions and influenced by temperature changes. For example, there was a study showing protein synthesis in rapeseed (Brassica napus) seedlings could continue at $0{ }^{\circ} \mathrm{C}$ 
while some polypeptides preferentially accumulate at this temperature, however, synthesis of several others is repressed while many are insensitive to cold treatment (Mezabasso et al., 1986). Each growth stage of each crop has its own temperature requirement for development and normal growth while it could cause prominent effects if crops did not grow in the proper temperature range. Transferring wheats (Triticum aestivum L.) from $21 / 16^{\circ} \mathrm{C}$ to $\mathrm{HT}$ of $36 / 31^{\circ} \mathrm{C}$ for intervals of 2 days in the period from head emergence to 10 days after anthesis resulted in grain sterility (Tashiro and Wardlaw, 1990). Temperature higher than $12^{\circ} \mathrm{C}$ is essential for the growth of normal rice seedling while below $20^{\circ} \mathrm{C}$ at panicle initiation may cause panicle sterility (Shimono et al., 2007). Moreover, there was a good negative correlation between temperature and oil level in the case of sunflower seeds (Shi et al., 2006a).

Rice is majorly produced and consumed in Asia where it accounts for up to $80 \%$ of the caloric requirement (Mahajan et al., 2010). Like other crops, rice which is recognized as a main staple food, also has its own suitable temperature ranges of each growth stages such as germination $\left(16-45^{\circ} \mathrm{C}\right)$, seedling emergence $\left(12-35^{\circ} \mathrm{C}\right)$, rooting $\left(16-35^{\circ} \mathrm{C}\right)$, tillering $\left(9-33{ }^{\circ} \mathrm{C}\right)$, panicle heading $\left(15-30{ }^{\circ} \mathrm{C}\right)$, anthesis $\left(22-35^{\circ} \mathrm{C}\right)$ and ripening $\left(12-30^{\circ} \mathrm{C}\right)$ (Nguyen, 2005). Meanwhile, a previous report demonstrated that temperature higher than $35^{\circ} \mathrm{C}$ at flowering stage affected rice reproductive growth severely causing spikelet sterility (Matsui et al., 2001). Furthermore, a study showed that the temperature range of $21-26^{\circ} \mathrm{C}$ was an optimal range at grain filling stage and temperature higher than $27^{\circ} \mathrm{C}$ may cause loss in grain weight (Tashiro and Wardlaw, 1990). In addition, Peng et al. (2004) indicated that yield of grain decreased by $10 \%$ for each $1{ }^{\circ} \mathrm{C}$ increase in growingseason minimum temperature in the dry season. Recently, a report declared that average temperatures from 23 to $29^{\circ} \mathrm{C}$ for rice is an optimal temperature range for rice during grain filling stage (Kobata et al., 2018). Moreover, Mo et al. (2016) published a study regarding effects of local climatic conditions and temperature fluctuations on productivity of rice in Guangzhou while suggesting South China should develop some strategies for crop improvement to address them.

There are a lot of physiological processes and biochemical substances which are sensitive to temperature such as photosynthesis, chlorophyll content, protein, reactive oxygen species (ROS) and chlorophyll fluorescence (Kong et al., 2017). For example, temperature at $33{ }^{\circ} \mathrm{C}$ in filling stage could cause decrease of chlorophyll content, maximal photochemical efficiency of PS II (F v/F m) and the potential photochemical efficiency of PS II (Fv/Fo) (Teng et al., 2008). High growth temperature and $\mathrm{CO}_{2}$ enrichment decreased the Rubisco content of rice by 22 and 23\% (Vu et al., 1997). An examination found that protein concentrations of rice leaves under high temperature at early ripening stage were higher than those of control temperature, but those were slowly decreased with no difference between temperature treatments since at mid ripening stage (Jiyoung et al., 2015).

This study was conducted in Guangdong province (major rice producing province in South China) in order to explore the effect of different temperature conditions on the physiological characteristics of rice leaves at filling stage.

\section{Materials and methods}

\section{Experimental details}

Seeds of two aromatic rice cultivars i.e., Basmati385 and Xiangyaxiangzhan (widely grown in South China and popular because of their special aroma and enchant flavor) 
were used in this study. Pot experiment between June 15th to July 13th in 2018 was conducted at Experimental Research Farm, College of Agriculture, South China Agricultural University, Guangzhou, $\left(23^{\circ} 09^{\prime} \mathrm{N}, 113^{\circ} 22^{\prime}\right.$ Eand $11 \mathrm{~m}$ from mean sea level) China. Before sowing, seeds of both cultivars were soaked in water for $24 \mathrm{~h}$ at room temperature and germinated at $37^{\circ} \mathrm{C}$, shade dried and the germinated seeds were sown in PVC trays for nursery while PVC trays were placed in puddled field and covered with a plastic sheet. Then, seedlings were transplanted into soil containing plastic pots (31 cm in diameter and $29 \mathrm{~cm}$ in height) in April. The experimental soil contained $24.56 \%$ organic matter content, $1.443 \%$ total nitrogen; $0.927 \%$ total phosphorous, $18.220 \%$ total potassium. At heading stage, the pots were translated into phytotron and treated as described below:

T1: $33{ }^{\circ} \mathrm{C}$ days and $27^{\circ} \mathrm{C}$ nights, under $1200 \mathrm{X}$ yellow light intensity and $75 \%$ humidity T2: $27^{\circ} \mathrm{C}$ days and $21^{\circ} \mathrm{C}$ nights, under $1200 \mathrm{X}$ yellow light intensity and $75 \%$ humidity T3: $21^{\circ} \mathrm{C}$ days and $15^{\circ} \mathrm{C}$ nights, under $1200 \mathrm{X}$ yellow light intensity and $75 \%$ humidity

There were fourteen pots for each treatment.

\section{Sampling collection}

The fresh leaves were sampled from the rice at the end of 7th, 14th, 21st and 28th day after heading stage (translated day, $\mathrm{d} \mathrm{AH}=$ day after heading stage). Samples were immediately stored at $-80^{\circ} \mathrm{C}$ for biochemical analyses.

\section{Determination of soluble protein and sugar}

The soluble protein content of leaves was estimated according to the methods of Bradford (1976). The absorbance was read at $595 \mathrm{~nm}$ and expressed as $\mu \mathrm{g} \mathrm{g}^{-1} \mathrm{FW}$ after reaction with G-250 while contents of soluble sugar was determined by using anthronesulfuric acid method (Wang et al., 2015).

\section{Determination of malondialdehyde (MDA) and anti-oxidants responses}

The malondialdehyde (MDA) content was measured according the method of Luo et al. (2017). MDA reacted with thiobarbituric acid (TBA) and the absorbance of was recorded at $532 \mathrm{~nm}, 600 \mathrm{~nm}$, and $450 \mathrm{~nm}$. The content of MDA was calculated as: MDA content $(\mu \mathrm{mol} / \mathrm{L})=6.45(\mathrm{OD} 532-\mathrm{OD} 600)-0.56 \mathrm{OD} 450$ and final result was expressed as $\mu \mathrm{mol} \mathrm{g}{ }^{-1} \mathrm{FW}$.

The peroxidase (POD EC1.11.1.7) activity was measured with the method of Luo et al. (2017). The reaction solution included enzyme extract $(50 \mu \mathrm{l})$ containing $1 \mathrm{ml}$ of $0.3 \%$ $\mathrm{H}_{2} \mathrm{O}_{2}, 0.95 \mathrm{ml}$ of $0.2 \%$ guaiacol, and $1 \mathrm{ml}$ of $50 \mathrm{mM} \mathrm{l}^{-1}$ sodium phosphate buffer ( $\mathrm{pH} 7.0$ ) while the absorbance was read at $470 \mathrm{~nm}$. One POD unit of enzyme activity was defined as the absorbance increase because of guaiacol oxidation by 0.01 ( $\mathrm{U} \mathrm{g} \mathrm{g}^{-1} \mathrm{FW}$ ). The superoxide (SOD, EC 1.15.1.1) activity was measured by using nitro blue tetrazolium (NBT) according to Ashraf et al. (2018). $0.05 \mathrm{ml}$ of enzyme extract was added into the

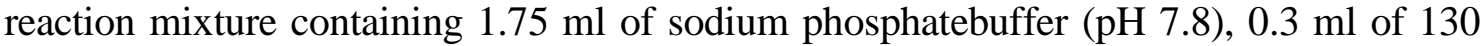
$\mathrm{mM} \mathrm{l^{-1 }}$ methionine buffer, $0.3 \mathrm{ml}$ of $750 \mu \mathrm{mol} \mathrm{l}^{-1}$ NBT buffer, $0.3 \mathrm{ml}$ of $100 \mu \mathrm{mol} \mathrm{l}^{-1}$ EDTA-Na 2 buffer and $0.3 \mathrm{ml}$ of $20 \mu \mathrm{mol} \mathrm{l}^{-1}$ lactoflavin. After reaction, the change in color was measured at $560 \mathrm{~nm}$. One unit of SOD activity is equal to the volume of extract needed to cause 50\% inhibition of the color reaction. Catalase (CAT, EC1.11.1.6) activity was estimated with the methods devised by Aebi (1984). An aliquot of enzyme extract $(50 \mu \mathrm{l})$ was added to the reaction solution containing $1 \mathrm{ml}$ of $0.3 \% \mathrm{H}_{2} \mathrm{O}_{2}$ and $1.95 \mathrm{ml}$ of 
sodium phosphate buffer and the absorbance was recorded at $240 \mathrm{~nm}$. One CAT unit of enzyme activity was defined as the absorbance decrease by $0.01\left(\mathrm{U} \mathrm{g}^{-1} \mathrm{FW}\right)$.

\section{Determination of chlorophyll contents}

The contents of photosynthetic pigment were determined by using $95 \%$ alcohol for the extraction (Lichtenthaler, 1987). The absorbance was read at $665 \mathrm{~nm}, 649 \mathrm{~nm}$, $652 \mathrm{~nm}$ and $470 \mathrm{~nm}$. The chlorophyll content was calculated as: chlorophyll a(Ca) $(\mathrm{mg} / \mathrm{L})=13.95$ OD665-6.88 OD649, chlorophyll b $(\mathrm{Cb})(\mathrm{mg} / \mathrm{L})=24.96$ OD649-7.32 OD665, total chlorophyll $(\mathrm{CT})(\mathrm{mg} / \mathrm{L})=$ OD652 $\times 1000 / 34.5$, carotenoid $=\left(\begin{array}{ll}1 & 000\end{array}\right.$ OD470-2.05Ca-114.8Cb)/245.

\section{Estimation of yield and yield related traits}

Rice from six randomly selected pots from each treatment were harvested at maturity stage. Then threshed manually and sun dried (adjusted to $\sim 15 \%$ moisture content) to get the grain yield per pot and expressed in grams per hill $\left(\mathrm{g} \mathrm{hill}{ }^{-1}\right)$. Panicle number per pot was determined by counting the panicle numbers of each hill in six different pots in each treatment and averaged. The grains were separated manually from each panicle in order to count total number of grains and filled grains per panicle. 1000-grain weight was recorded by counting six random samples from filled grains, weighed and averaged.

\section{Statistical analyses}

This study was managed as a split block design. Data were analyzed using statistical software 'Statistix 8.1' (Analytical Software, Tallahassee, FL, USA) while differences amongst means were separated by using least significant difference (LSD) test at 5\% probability level. 'Origin 8.1' (OriginLab Co., Northampton, MA, USA) was used for graphical representation.

\section{Results}

\section{Chlorophyll content}

As showed in Figure 1, there were some differences in chlorophyll contents under different thermostatic conditions. The contents of total chlorophyll, chlorophyll a and chlorophyll $\mathrm{b}$ gradually decreased along with the grain filling process. The highest total chlorophyll content was recorded in T1 for both cultivars at 7, 14, 21 days after heading (d AH). Furthermore, the trend for total chlorophyll content at 7 and $14 \mathrm{~d} \mathrm{AH}$ was recorded as: T1 > T2 > T3, whereas at 21d AH higher total chlorophyll was recorded in T3 than T2 for Basmati385 while there was no significant difference between the three treatments for Xiangyaxiangzhan. At $28 \mathrm{DAH}$, there was no significant difference in chlorophyll content of the three treatments for both Basmati385 and Xiangyaxiangzhan. Meanwhile, all values of chlorophyll $a$ and chlorophyll $b$ in both cultivars were remained statistically similar with total chlorophyll.

\section{Anti-oxidant enzyme activities}

Different temperature at filling stage affected the anti-oxidative enzyme activities in terms of SOD, POD and CAT (Fig. 2a-f). The trend for POD activity was recorded as: 
$\mathrm{T} 1>\mathrm{T} 2>\mathrm{T} 3$ at $7 \mathrm{~d}$ AH for both cultivars. At $14 \mathrm{~d} \mathrm{AH}$, both $\mathrm{T} 1$ and $\mathrm{T} 3$ remained higher activity of POD than T2 for Basmati whilst the trend of POD activity was recorded as $\mathrm{T} 3>\mathrm{T} 2>\mathrm{T} 1$ for Xiangyaxiangzhan. At 21d AH, the maximum POD activity was recorded in $\mathrm{T} 1$ while the minimum value was in $\mathrm{T} 3$ for Basmati. However, for Xiangyaxiangzhan, highest POD activity was recorded in T2 and lowest value was in T1. At $28 \mathrm{~d} \mathrm{AH}$, there was no significant difference of POD activity between T1 and T2 for both cultivars while the value of T3 was remained lowest for Basmati and highest for Xiangyaxiangzhan.
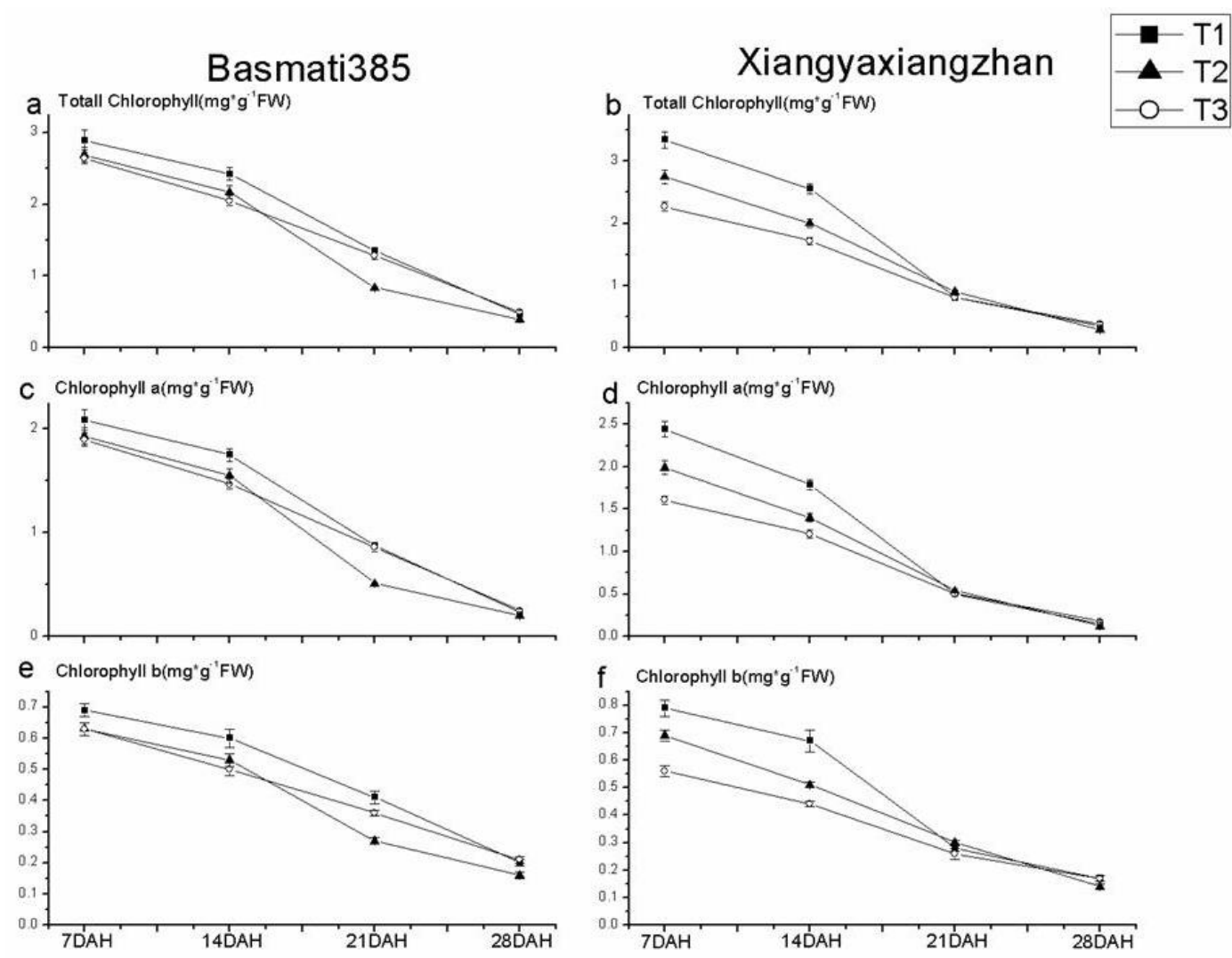

Figure 1. Effect of different temperature conditions at filling stage on chlorophyll content (d $A H=$ days after heading, $F W$ mean fresh weigh, $T 1$ mean T1 treatment $\left(33^{\circ} \mathrm{C} / 27^{\circ} \mathrm{C}\right)$, T2 mean T2 treatment $\left(27^{\circ} \mathrm{C} / 21^{\circ} \mathrm{C}\right)$, T3 mean T3 treatment $\left(21^{\circ} \mathrm{C} / 15^{\circ} \mathrm{C}\right)$, the same as below)

SOD activity was affected differently under different temperature conditions at filling stage. SOD activity in T1 remained at highest level at 7, 14, 21 and 28d AH while the trends at 7, 14, 21d AH were recorded as: T1 > T2 > T3 for both cultivars. At 28d AH, SOD activities of T1 and T2 remained similar while T3 was lower than both $\mathrm{T} 1$ and T2 for Basmati. However, there was no significant difference between T2 and $\mathrm{T} 3$ whilst the highest value was recorded in T1 for Xiangyaxiangzhan.

The highest CAT activity was recorded in $\mathrm{T} 1$ at $7,14 \mathrm{~d} \mathrm{AH}$ for both cultivars. Meanwhile, the trends for CAT activities at 7, 14d AH were recorded as: T1 > T2 > T3. At $21 \mathrm{DAH}$, there was no significant difference between $\mathrm{T} 1$ and $\mathrm{T} 3$ while $\mathrm{T} 2$ remained at the lowest level for Basmati while values of three treatments were similar for Xiangyaxiangzhan. Moreover, activities of CAT remained similar in the three treatments at $28 \mathrm{~d} \mathrm{AH}$ for both cultivars. 

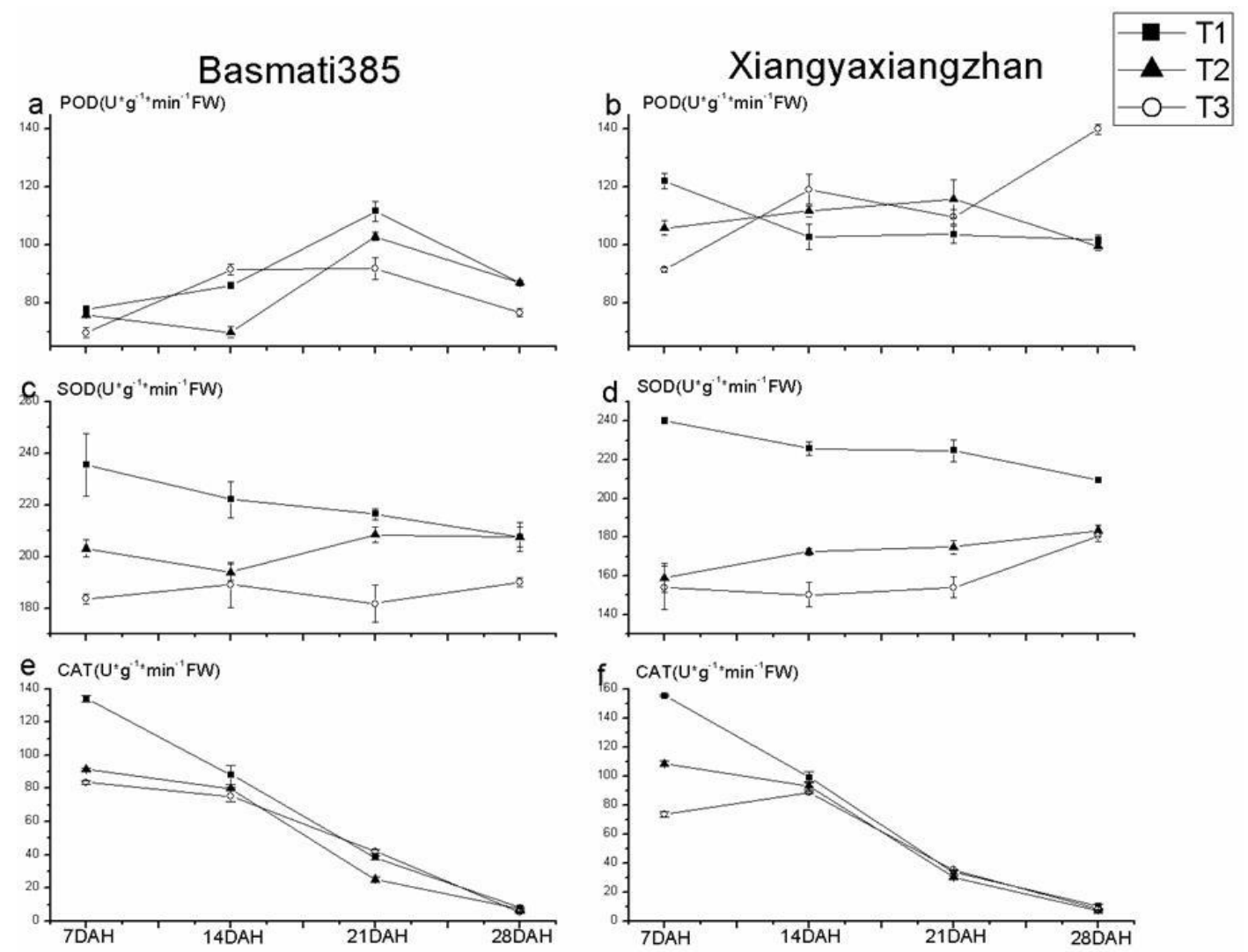

Figure 2. Effect of different temperature conditions at filling stage on anti-oxidant enzyme activities

\section{MDA and soluble protein contents}

MDA contents were affected differently under different temperature conditions at filling stage (Table 1). At 7d AH, the trend was recorded as $\mathrm{T} 1>\mathrm{T} 3>\mathrm{T} 2$ for Basmati while T3 > T2 > T1 for Xiangyaxiangzhan. Whereas at 14d AH, CAT activity of T3 was lower than both $\mathrm{T} 1$ and $\mathrm{T} 2$ for Basmati385 whilst there was no significant difference among T1, T2 and T3 for Xiangyaxiangzhan. At 21d AH, activities of CAT in T1, T2 and T3 remained similar for Basmati385 while value of T1 was lower than both T2 and T3 for Xiangyaxiangzhan. At 28d AH, for Basmati385, values of T1 and T2 remained similar and higher than T3. For Xiangyaxiangzhan maximum was recorded in T1 while there was no significant difference between T2 and T3.

Table 1. Effect of different temperature conditions at filling stage on MDA and soluble protein contents

\begin{tabular}{|c|c|c|c|c|c|c|c|c|c|}
\hline \multirow{2}{*}{ Cultivar } & \multirow{2}{*}{ Treatment } & \multicolumn{4}{|c|}{ MDA } & \multicolumn{4}{|c|}{ Soluble protein } \\
\hline & & 7DAH & 14DAH & 21DAH & 28DAH & 7DAH & 14DAH & 21DAH & 28DAH \\
\hline \multirow{3}{*}{ Basmati } & $\mathrm{T} 1$ & $3.19 \pm 0.01 \mathrm{a}$ & $5.66 \pm 0.04 \mathrm{a}$ & $5.40 \pm 0.68 \mathrm{a}$ & $4.51 \pm 0.23 \mathrm{a}$ & $129.72 \pm 2.89 a$ & $72.41 \pm 9.42 b$ & $69.41 \pm 1.93 \mathrm{a}$ & $23.41 \pm 0.30 \mathrm{~b}$ \\
\hline & $\mathrm{T} 2$ & $2.19 \pm 0.06 \mathrm{c}$ & $5.46 \pm 0.02 \mathrm{a}$ & $5.89 \pm 0.10 \mathrm{a}$ & $3.50 \pm 0.18 \mathrm{~b}$ & $130.74 \pm 7.71 \mathrm{a}$ & $111.69 \pm 3.98 \mathrm{a}$ & $47.38 \pm 9.22 b$ & $33.26 \pm 3.15 \mathrm{a}$ \\
\hline & $\mathrm{T} 3$ & $2.68 \pm 0.01 b$ & $3.28 \pm 0.15 b$ & $5.51 \pm 0.08 \mathrm{a}$ & $4.66 \pm 0.11 \mathrm{a}$ & $129.78 \pm 2.12 \mathrm{a}$ & $109.84 \pm 2.06 \mathrm{a}$ & $68.04 \pm 4.04 \mathrm{a}$ & $31.10 \pm 4.27 \mathrm{a}$ \\
\hline \multirow{3}{*}{ Xiangyaxiangzhan } & $\mathrm{T} 1$ & $1.96 \pm 0.05 \mathrm{c}$ & $6.03 \pm 0.18 \mathrm{a}$ & $4.16 \pm 0.43 b$ & $3.54 \pm 0.12 \mathrm{a}$ & $155.78 \pm 3.18 \mathrm{a}$ & $76.04 \pm 5.64 b$ & $60.21 \pm 1.63 b$ & $19.98 \pm 1.44 \mathrm{~b}$ \\
\hline & $\mathrm{T} 2$ & $2.95 \pm 0.05 b$ & $6.21 \pm 0.30 \mathrm{a}$ & $6.36 \pm 0.22 \mathrm{a}$ & $2.38 \pm 0.13 b$ & $133.41 \pm 4.94 b$ & $71.55 \pm 2.18 \mathrm{~b}$ & $59.14 \pm 1.28 \mathrm{~b}$ & $20.47 \pm 1.49 b$ \\
\hline & $\mathrm{T} 3$ & $3.42 \pm 0.05 \mathrm{a}$ & $6.24 \pm 0.14 \mathrm{a}$ & $5.94 \pm 0.33$ & $2.79 \pm 0.03 b$ & $109.75 \pm 1.77 \mathrm{c}$ & $115.94 \pm 6.67 \mathrm{a}$ & $67.47 \pm 2.21 \mathrm{a}$ & $4.59 \pm 2.55 \mathrm{a}$ \\
\hline
\end{tabular}

Means in the same column followed by different lower case letters for the same variety differ significantly at $\mathrm{P}<0.05$ by $\mathrm{T}$-test, the same as below 
There were some differences on soluble protein content under different temperatures at filling stage (Table 1). The content of soluble protein in T1, T2 and T3 were remained similar at $7 \mathrm{~d} \mathrm{AH}$ for Basmati and the trend for Xiangyaxiangzhan was recorded as: $\mathrm{T} 1>\mathrm{T} 2>\mathrm{T} 3$. Minimum content of soluble protein was recorded in $\mathrm{T} 1$ at $14 \mathrm{~d}$ AH for Basmati385 while maximum was observed in T3 for Xiangyaxiangzhan. At $21 \mathrm{~d} \mathrm{AH}$, content in T2 was lower than T1 and T3 for Basmati385 while T3 was higher than both T1 and T2 for Xiangyaxiangzhan. At 28d AH, soluble content of T2 and T3 remained similar and higher than T1 for Basmati385. However, for Xiangyaxiangzhan, there was no significant difference between $\mathrm{T} 1$ and $\mathrm{T} 2$ whilst the maximum was recorded in $\mathrm{T} 3$.

\section{Correlation analysis between anti-oxidative enzyme, soluble protein and MDA}

As shown in Table 2, a significant positive correlation exists between CAT activity and soluble protein content $(\mathrm{r}=0.9128, \mathrm{P}<0.01)$ and a significant positive correlation between CAT activity and total chlorophyll content $(\mathrm{r}=0.9659, \mathrm{P}<0.01)$. Besides, the total chlorophyll content and soluble protein content also had a significant positive correlation $(\mathrm{r}=0.9328, \mathrm{P}<0.01)$.

Table 2. Relationship between anti-oxidative enzymatic activities and MDA

\begin{tabular}{c|c|c|c|c|c}
\hline Index & POD & SOD & CAT & MDA & Protein \\
\hline SOD & -0.2582 & & & & \\
CAT & -0.0921 & 0.0948 & & & \\
MDA & 0.1330 & -0.1259 & -0.1517 & & \\
Protein & -0.1558 & -0.0771 & $0.9128^{* *}$ & -0.2546 & \\
Total chlorophyll & -0.2332 & 0.0986 & $0.9659^{* *}$ & -0.1958 & $0.9328^{* *}$ \\
\hline
\end{tabular}

Significant correlations at $* \mathrm{P}<0.05$ and $* * \mathrm{P}<0.01$

\section{Yield and yield related traits}

As shown in Table 3, for Basmati385, there was no significant difference in panicle number, grains per panicle and 1000-grain weight at different temperatures whilst in grain filling percentage, T2 was higher than both $\mathrm{T} 1$ and $\mathrm{T} 3$ while there was no significant difference betweenT1 and T3. Furthermore, the trend of yield was recorded as: $\mathrm{T} 2>\mathrm{T} 1>\mathrm{T} 3$. For Xiangyaxiangzhan, there also was no significant difference in grains per panicle, however, the trend of panicle number was recorded as: T3 > T1 > T2 whilst the highest 1000-grain weight was recorded in T1. Moreover, grain filling percentage of T3 was lower than both $\mathrm{T} 1$ and $\mathrm{T} 2$ while no significant difference between $\mathrm{T} 1$ and $\mathrm{T} 2$ and same pattern was found in yield.

\section{Relationship between yield and yield related traits}

As shown in Table 4, a significant positive correlation exists between yield and grain filling percentage. Panicle number per hill had negative correlation with both 1000grain weight and grains number per panicle, however, it had a significant positive correlation with panicle number per hill and grain filling percentage. Furthermore, grain filling percentage had negative correlation with grains number per panicle. 
Table 3. Effect of different temperature conditions at filling stage on yield and yield related traits

\begin{tabular}{|c|c|c|c|c|c|c|}
\hline Cultivars & Treatments & $\begin{array}{c}\text { Panicle number } \\
\left(\text { hill }^{-1}\right)\end{array}$ & $\begin{array}{c}\text { Grains per } \\
\text { panicle }\end{array}$ & $\begin{array}{c}\text { Grain filling } \\
\text { percentage }(\%)\end{array}$ & $\begin{array}{c}\text { 1000-grain } \\
\text { weight }(\mathrm{g})\end{array}$ & $\begin{array}{c}\text { Yield } \\
\left(\mathrm{g} \cdot \text { hill }^{-1}\right)\end{array}$ \\
\hline \multirow{3}{*}{ Basmati 385} & $\mathrm{~T} 1$ & $6.67 \pm 0.34 \mathrm{a}$ & $107.83 \pm 9.64 \mathrm{a}$ & $56.51 \pm 1.61 b$ & $27.65 \pm 0.25 \mathrm{a}$ & $10.51 \pm 0.13 b$ \\
\hline & $\mathrm{T} 2$ & $6.33 \pm 0.33 \mathrm{a}$ & $102.06 \pm 1.33 \mathrm{a}$ & $71.77 \pm 6.95 \mathrm{a}$ & $27.42 \pm 0.23 \mathrm{a}$ & $11.39 \pm 0.71 \mathrm{a}$ \\
\hline & $\mathrm{T} 3$ & $6.00 \pm 0.34 \mathrm{a}$ & $92.13 \pm 3.66 \mathrm{a}$ & $57.12 \pm 3.14 \mathrm{~b}$ & $27.55 \pm 0.10 \mathrm{a}$ & $9.91 \pm 0.13 \mathrm{c}$ \\
\hline \multirow{3}{*}{ Xiangyaxiangzhan } & $\mathrm{T} 1$ & $9.33 \pm 0.33 \mathrm{ab}$ & $79.58 \pm 5.10 \mathrm{a}$ & $85.05 \pm 2.62 \mathrm{a}$ & $20.35 \pm 0.31 \mathrm{a}$ & $11.82 \pm 0.47 \mathrm{a}$ \\
\hline & $\mathrm{T} 2$ & $7.67 \pm 0.67 b$ & $87.52 \pm 9.18 \mathrm{a}$ & $87.93 \pm 0.44 a$ & $19.48 \pm 0.05 b$ & $11.29 \pm 0.30 \mathrm{a}$ \\
\hline & $\mathrm{T} 3$ & $10.5 \pm 0.28 \mathrm{a}$ & $10.11 \pm 4.86 \mathrm{a}$ & $78.90 \pm 3.92 b$ & $19.74 \pm 0.13 b$ & $10.38 \pm 0.30 \mathrm{~b}$ \\
\hline
\end{tabular}

Table 4. Relationship between yield and yield related traits

\begin{tabular}{c|c|c|c|c}
\hline Index & $\begin{array}{c}\text { Panicle number } \\
\text { per hill }\end{array}$ & $\begin{array}{c}\text { 1000-grain } \\
\text { weight }\end{array}$ & $\begin{array}{c}\text { Grain filling } \\
\text { percentage }\end{array}$ & $\begin{array}{c}\text { Grains number } \\
\text { per panicle }\end{array}$ \\
\hline 1000-grain weight & $-0.8077^{* *}$ & & & \\
Grain filling percentage & $0.5713^{*}$ & $-0.8152^{* *}$ & & \\
Grains number per panicle & $-0.8399^{* *}$ & $0.6764^{* *}$ & $-0.6577^{* *}$ & \\
Yield & 0.1327 & -0.3111 & $0.6499^{* *}$ & -0.2131 \\
\hline
\end{tabular}

\section{Discussion}

Crop production is affected by many factors: sowing, topography, fertilization, and temperature flux. Among all of them, temperature is one of most important part in plant growth and development. For example, high temperature could trigger shortened vegetative phase and steep rise in temperature at the grain filling stage may cause abortion of florets and reduced kernel weight (Alam, 2012) and low temperature could inhibit biomass accumulation of rice seeding and cause the loss of chlorophyll (Bevilacqua et al., 2015). Meanwhile, the Chlorophylls and antioxidant responses are important phenomena in plants which could be affected significantly by temperature. Green plants use light to carry out photosynthesis through chlorophyll, converting carbon dioxide and water into organic compounds that store energy, such as starch, while releasing oxygen. Pigment in the chloroplasts includes two categories: the chlorophyll and carotenoid, chlorophyll including chlorophyll a and chlorophyll $b$, chloroplast pigments can absorb light energy, but only a few special conditions of chlorophyll a has a role in the conversion of light energy, which means most carotenoids and chlorophyll $b$ pass light energy they absorb to a handful of chlorophyll a, and under special conditions the light energy is transformed into electricity and chemical energy (Haworth et al., 2018; Dalal and Tripathy, 2018). It will be visible, a few special conditions of chlorophyll a has the function of the absorption and conversion of light energy, and most of the chlorophyll a and chlorophyll $b$ all have the function of the absorption and transmission of light (Mauzerall, 1976). At filling stage of rice, $80 \%$ of photo assimilate from leaves were absorbed by filling grains (Chen et al., 2005). A previous study showed that there exist a positive correlation between SPAD readings and rice yield (Gholizadeh et al., 2017). Another research (Gilani et al., 2009) also indicated that heat stress cause loss of rice yields by decreasing the chlorophyll content and disturbing cell membrane stability. The study of Peng (2004) and Prasad et al. (2008) also found 14\% reduction in leaf photosynthesis due to high 
temperature. Besides, Gosavi et al. (2014) found that high temperature could cause decrease of chlorophyll content and increase activities of SOD, POD and CAT because higher activity of antioxidant enzymes might be able to cope with oxidative damage by heat stress under high temperature condition. Furthermore, MDA production is also an important indicator of oxidative stress because of imparting the characteristics of interand intracellular membranes (Dash and Mohanty, 2002). In addition, a previous report showed that the protein contents in rice leaves decreased to $53 \%$ with an increase in temperature from 28 to $34{ }^{\circ} \mathrm{C}$, while the protein reduction rate was lower (47\%) under a further increase in temperature to $40{ }^{\circ} \mathrm{C}$ (Gesch et al., 2003). Moreover, there was a decrease of protein content in rice when exposed to $39^{\circ} \mathrm{C}$, compared with average temperature of $32{ }^{\circ} \mathrm{C}$ (Tang et al., 2008).

In this study, environment temperature at filling stage affected chlorophyll content significantly for both cultivars. We observed that the total chlorophyll content in flag leaves at 7, $14 \mathrm{DAH}$ increased with the rise of temperature in certain range while content of total chlorophyll decreased gradually after heading stage. Similar trends were also recorded in contents of both chlorophyll a and chlorophyll b (Fig. 1). Those results agreed the study of Cai et al. (2015) which indicated that the elevated temperature improved 0.8 SPAD leaf chlorophyll content and leaf area index. The increment of chlorophyll meant a certain range of temperature increase at filling stage could promote leaf chlorophyll synthesis so increase the contents of chlorophyll and even enhance the photosynthesis. The reason may be that the temperature increase in a certain range could enhance the chemical reaction rate inside flag leaves of rice so that the activity of chlorophyll synthase was improved to promote the synthesis of chlorophyll. A similar study was also conducted by Wei and Pan (2008), which found that the nocturnal temperature of the whole growth period significantly affected each period of early rice growth. The higher night temperature is beneficial to the growth of early rice seedling stage and tilling stage, improving the quality of seedling and chlorophyll contents. A previous study (Mohanty et al., 2006) indicated that chloroplast development and chlorophyll biosynthesis were influenced significantly by temperature and light whilst their report implied the presence of both light and heat-inducible elements in their promoters because light and heat-stress stimulated glutamate semi aldehyde aminotransferase and uroporphyrinogen decarboxylase gene (UroD) and gene product abundance. In addition, the contents of total chlorophyll, chlorophyll a and chlorophyll $\mathrm{b}$ in T3 remained at a lower level than in both T1 and T2 at 7 and 14 DAH. Those values maybe mean that if the temperature is lower than $22^{\circ} \mathrm{C}$ at filling stage it could cause reduction of chlorophyll.

Furthermore, we observed that the activities of POD, SOD and CAT had different responses to temperature at filling stage. Antioxidant enzymes which were including POD, SOD and CAT play an important part in detoxifying active oxygen species while antioxidant enzymes aid cells in removing harmful oxygen species (Pan et al., 2013). At early grouting stage (7DAH), there is no significant difference in POD activity between $\mathrm{T} 1$ and T2 while in T3 it remained low. However, POD activity in T3 increased drastically at middle stage and became higher than both $\mathrm{T} 1$ and T2. Furthermore, the activities of SOD and CAT in T3 remained lower than in T1 and T2 in a whole filling stage. Those reductions were similar with the study of Bonnecarrère et al. (2011) which found low temperature could reduce activities of antioxidant enzymes or cause a significant change. Both SOD and CAT are essential components of plants oxidative defence system in removal of toxic peroxides. It is mostly universal oxidoreductase that 
scavenges $\mathrm{H}_{2} \mathrm{O}_{2}$ via a two electron transfer producing $\mathrm{O}_{2}$ and $\mathrm{H}_{2} \mathrm{O}$ (Shah et al., 2001). The antioxidant enzymes such as POD, SOD and CAT are effective quenchers of ROS whilst their level may also represent the sensitivity of plants to lipid peroxidation (Imamura et al., 2000). According to the values of our study, the temperature condition lower than $22{ }^{\circ} \mathrm{C}$ at filling stage might have formed a cold stress to rice. Meanwhile, highest activities of SOD and CAT were recorded in T1 at both 7 and 14 DAH. The main reason might be the environment temperature of $\mathrm{T} 1$ that might already formed a heat stress to rice, however, the stress of this degree cannot do much damage to rice and the plants just need enhancement in the activity of antioxidant enzymes so they can remove the damage mostly. The result of yield confirmed this infer by showing the yield of $\mathrm{T} 2$ was higher than $\mathrm{T} 1$ in Basmati and in Xiangyaxiangzhan, there was no significant difference between $\mathrm{T} 1$ and $\mathrm{T} 2$. In addition, the contents of protein also decreased with filling process and it had a significant positive relation with CAT activities. This result agree with Sairam et al. (2000) who found proteins have a significant role in osmo-regulations and in the maintenance of cellular structures when anti-oxidants quench reactive oxygen species (ROS).

\section{Conclusion}

In conclusion, a temperature of $33{ }^{\circ} \mathrm{C} / 27^{\circ} \mathrm{C}$ at filling stage could enhance the biosynthesis and accumulation of chlorophylls in the early phase. However, $33{ }^{\circ} \mathrm{C} / 27^{\circ} \mathrm{C}$ would also create some sight stress resistance to rice. Moreover, a temperature of $21 / 15^{\circ} \mathrm{C}$ not only would reduce the content of chlorophylls but also would lower the activities of anti-oxidative enzyme. Compared with $33{ }^{\circ} \mathrm{C} / 27^{\circ} \mathrm{C}$ and $21 / 15^{\circ} \mathrm{C}$, a temperature of $27^{\circ} \mathrm{C} / 21^{\circ} \mathrm{C}$ was regarded as the most suitable temperature at filling stage for rice. In order to reveal the mechanism of chlorophyll synthesis and antioxidant responses under different temperature conditions at filling stage, further research should be done at molecular and physiological level.

Acknowledgements. This study was supported by the National Natural Science Foundation of China (31271646), the National Key R\&D Program of China (2016YFD0700301), Graduate Student Overseas Study Program of South China Agricultural University (2017LHPY004), The World Bank Loan Agricultural Pollution Control Project in Guangdong (0724-1510A08N3684), The Technology System of Modern Agricultural Industry in Guangdong (2017 LM1098) and the Student's Platform for Innovation and Entrepreneurship Training Program (201810564029). The authors declare no conflicts of interest.

\section{REFERENCES}

[1] Aebi, H. (1984): Catalase in vitro. - Methods Enzymol 105: 121-126.

[2] Alam, M. Z (2012): Growth, Yield and Nitrogen Utilization of Barley. - LAP Lambert Academic Publishing, Riga.

[3] Almeselmani, M., Deshmukh, P. S., Sairam, R. K., Kushwaha, S. R., Singh, T. P. (2006): Protective role of antioxidant enzymes under high temperature stress. - Plant Science An International Journal of Experimental Plant Biology 171: 382-388.

[4] Ashraf, U., Hussain, S., Akbar, N., Anjum, S. A., Hassan, W., Tang, X. (2018): Water management regimes alter $\mathrm{Pb}$ uptake and translocation in fragrant rice. - Ecotoxicology and Environmental Safety 149: 128-134.

[5] Atkin, O. K., Tjoelker, M. G. (2003): Thermal acclimation and the dynamic response of plant respiration to temperature. - Trends in Plant Science 8: 343. 
[6] Berry, J., Bjorkman, O. (2003): Photosynthetic response and adaptation to temperature in higher plants. - Annual Review of Plant Physiology 31: 491-543.

[7] Bevilacqua, C. B., Borges, C. T., Venske, E., Almeida, A. D. S., Zimmer, P. D. (2015): Biomass accumulation and chlorophyll content in rice cultivars seedlings under cold stress. - Scientia Agraria Paranaensis 14(4): 229-233.

[8] Bonnecarrère, V., Borsani, O., Díaz, P., Capdevielle, F., Blanco, P., Monza, J. (2011): Response to photoxidative stress induced by cold in japonica rice is genotype dependent. - Plant Science An International Journal of Experimental Plant Biology 180: 726.

[9] Bradford, M. M. (1976): A rapid and sensitive method for the quantitation of microgram quantities of protein utilizing the principle of protein-dye binding. - Analytical Biochemistry 72: 248-254.

[10] Cai, W. W., Wan, Y. F., Tian-Cheng, A. I., You, S. C., Yu-E, L. I., Wang, B. (2015): Impacts of elevated CO_2 concentration and temperature increasing on growth and yield of late rice. - Chinese Journal of Agrometeorology 36(6): 717-723.

[11] Chen, H., Tao, L., Wang, X., Huang, X., Tan, H., Cheng, S., Min, S. (2005): Effect of different irrigation modes during grain filling of rice on translocation and allocation of carbohydrate in rice. - Scientia Agricultura Sinica 38(4): 678-683.

[12] Dalal, V. K., Tripathy, B. C. (2018): Water-stress induced downsizing of light-harvesting antenna complex protects developing rice seedlings from photo-oxidative damage. Scientific Reports 8: 5955.

[13] Dash, S., Mohanty, N. (2002): Response of seedlings to heat-stress in cultivars of wheat: Growth temperature-dependent differential modulation of photosystem 1 and 2 activity, and foliar antioxidant defense capacity. - Journal of Plant Physiology 159: 49-59.

[14] Gesch, R. W., Kang, I. H., Gallo-Meagher, M., Vu, J. C. V., Boote, K. J., Allen, L. H., Bowes, G. (2003): Rubisco expression in rice leaves is related to genotypic variation of photosynthesis under elevated growth $\mathrm{CO} 2$ and temperature. - Plant Cell \& Environment 26: 1941-1950.

[15] Gholizadeh, A., Saberioon, M., Borůvka, L., Wayayok, A., Soom, M. A. M. (2017): Leaf chlorophyll and nitrogen dynamics and their relationship to lowland rice yield for sitespecific paddy management. - Information Processing in Agriculture 4(4): 259-268.

[16] Gilani, A. A., Siadat, S. A., Alamisaeed, K., Bakhshandeh, A. M., Moradi, F., Seidnejad, M. (2009): Effect of heat stress on grain yield stability, chlorophyll content and cell membrane stability of flag leaf in commercial rice cultivars in Khuzestan. - Iranian Journal of Crop Science 11(1): 82-100.

[17] Gosavi, G. U., Jadhav, A. S., Kale, A. A., Gadakh, S. R., Pawar, B. D., Chimote, V. P. (2014): Effect of heat stress on proline, chlorophyll content, heat shock proteins and antioxidant enzyme activity in sorghum (Sorghum bicolor) at seedlings stage. - Indian Journal of Biotechnology 13: 356-363.

[18] Haworth, M., Belcher, C. M., Killi, D., Dewhirst, R. A., Materassi, A., Raschi, A., Centritto, M. (2018): Impaired photosynthesis and increased leaf construction costs may induce floral stress during episodes of global warming over macroevolutionary timescales. - Scientific Reports 8: 6206.

[19] Imamura, S., Yanase, K., Horiguchi, M., Ozaki, M., Wakai, Y. (2000): Changes in antioxidative enzymes in cucumber cotyledons during natural senescence: comparison with those during dark-induced senescence. - Physiologia Plantarum 109: 211-216.

[20] Jiyoung, S., Junhwan, K., Chungkuen, L., Yang, W. H. (2015): Effect of high temperature on leaf physiological changes as chlorophyll composition and photosynthesis rate of rice. - Korean Journal of Crop Science 60: 266-272.

[21] Kobata, T., Palta, J. A., Tanaka, T., Ohnishi, M., Maeda, M., Cedilla, M. K., Barutçular, C. (2018): Responses of grain filling in spring wheat and temperate-zone rice to temperature: Similarities and differences. - Field Crops Research 215: 187-199.

[22] Kong, L., Ashraf, U., Cheng, S., Rao, G., Mo, Z., Tian, H., Pan, S., Tang, X. (2017): Short-term water management at early filling stage improves early-season rice 
performance under high temperature stress in South China. - European Journal of Agronomy 90: 117-126.

[23] Lichtenthaler, H. K. (1987): Chlorophylls and carotenoids: Pigments of photosynthetic biomembranes. - Methods in Enzymology 148C: 350-382.

[24] Luo, H., Zhong, Z., Nie, J., Tang, X. (2017): Effects of ultrasound on physiological characters, yield and quality of rice Yuejingsimiao. - China Rice 27(2): 64-67.

[25] Mahajan, G., Sekhon, N. K., Singh, N., Kaur, R., Sidhu, A. S. (2010): Yield and nitrogenuse efficiency of aromatic rice cultivars in response to nitrogen fertilizer. - Journal of New Seeds 11: 356-368.

[26] Matsui, T., Omasa, K., Horie, T. (2001): The difference in sterility due to high temperatures during the flowering period among Japonica-rice varieties. - Plant Production Science 4: 90-93.

[27] Mauzerall, D. (1976): Chlorophyll and photosynthesis. - Philosophical Transactions of the Royal Society B Biological Sciences 273: 287-294.

[28] Mezabasso, L., Alberdi, M., Raynal, M., Ferrerocadinanos, M. L., Delseny, M. (1986): Changes in protein synthesis in rapeseed (Brassica napus) seedlings during a low temperature treatment. - Plant Physiology 82: 733-8.

[29] Mo, Z. W., Pan, S. G., Ashraf, U., Kanu, A. S., Li, W., Wang, Z. M., Duan, M. Y., Tian, H., Kargbo, M. B., Tang, X. R. (2016): Local climate affects growth and grain productivity of precision hill-direct-seeded rice in South China. - Applied Ecology \& Environmental Research 15: 113-125.

[30] Mohanty, S., Grimm, B., Tripathy, B. C. (2006): Light and dark modulation of chlorophyll biosynthetic genes in response to temperature. - Planta 224: 692.

[31] Nguyen, N. V. (2005): Global climate changes and rice food security. - International Rice Commission Newsletter (FAO) 54: 24-30.

[32] Pan, S., Rasul, F., Li, W., Tian, H., Mo, Z., Duan, M., Tang, X. (2013): Roles of plant growth regulators on yield, grain qualities and antioxidant enzyme activities in super hybrid rice (Oryza sativa L.). - Rice 6: 1-10.

[33] Peng, S., Huang, J., Sheehy, J. E., Laza, R. C., Visperas, R. M., Zhong, X., Centeno, G. S., Khush, G. S., Cassman, K. G. (2004): Rice yields decline with higher night temperature from global warming. - Proceedings of the National Academy of Sciences of the United States of America 101: 9971-5.

[34] Prasad, P. V. V., Staggenborg, S. A., Ristic, Z. (2008): Impacts of Drought and/or Heat Stress on Physiological, Developmental, Growth, and Yield Processes of Crop Plants. In: Ahuja, L. R., Reddy, V. R., Saseendran, S. A., Qiang, Y. U. (eds.) Response of Crops to Limited Water: Understanding and Modeling Water Stress Effects on Plant Growth Processes, Advances in Agricultural Systems Modeling 1. American Society of Agronomy, Madison, WI, pp. 301-355.

[35] Sairam, R. K., Srivastava, G. C., Saxena, D. C. (2000): Increased antioxidant activity under elevated temperatures: a mechanism of heat stress tolerance in wheat genotypes. Biologia Plantarum 43: 245-251.

[36] Shah, K., Kumar, R. G., Verma, S., Dubey, R. S. (2001): Effect of cadmium on lipid peroxidation, superoxide anion generation and activities of antioxidant enzymes in growing rice seedlings. - Plant Science 161: 1135-1144.

[37] Shi, Q., Bao, Z., Zhu, Z., Ying, Q., Qian, Q. (2006a): Effects of different treatments of salicylic acid on heat tolerance, chlorophyll fluorescence, and antioxidant enzyme activity in seedlings of Cucumis sativa L. - Plant Growth Regulation 48: 127-135.

[38] Shimono, H., Okada, M., Kanda, E., Arakawa, I. (2007): Low temperature-induced sterility in rice: Evidence for the effects of temperature before panicle initiation. - Field Crops Research 101: 221-231.

[39] Tang, R. S., Zheng, J. C., Jin, Z. Q., Zhang, D. D., Huang, Y. H., Chen, L. G. (2008): Possible correlation between high temperature-induced floret sterility and endogenous 
levels of IAA, GAs and ABA in rice (Oryza sativa L.). - Plant Growth Regulation 54: 3743.

[40] Teng, Z. H., Zhi, L., Zong, X. F., Wang, S. G., He, G. H. (2008): Effects of high temperature on chlorophyll fluorescence, active oxygen resistance activity, and grain quality in grain-filling periods in rice plants. - Acta Agronomica Sinica 34: 1662-1666.

[41] Vu, J. C. V., Allen Jr, L. H., Boote, K. J., Bowes, G. (1997): Effects of elevated CO2 and temperature on photosynthesis and Rubisco in rice and soybean. - Plant Cell \& Environment 20: 68-76.

[42] Wang, C. C., Kong, L. L., Mei-Juan, L. I., Tang, X. R., Yao-Dong, D. U., Wang, H. (2015): Effect of water treatments at tillering stage on super rice yield and physiological characteristics. - Acta Agriculturae Boreali-Sinica 30(5): 146-152.

[43] Wei, J. L., Pan, X. H. (2008): Effects of night temperature increase on growth and yield of early season rice. - Acta Agriculturae Universitatis Jiangxiensis 30: 427-432. 